\title{
Expression of 3 $\beta$-Hydroxysteroid dehydrogenase and P450 side chain cleavage enzyme in the human uterine endometrium
}

\author{
Hee Sub Rhee', Seon Hee $\mathrm{Oh}^{2}$, Bum Joo Koㄹ, \\ Dong Min Han ${ }^{2}$, Byung Hun Jeon ${ }^{3}$, \\ Hyun Park, Hyung Bae Moon ${ }^{5}$ and \\ Won Sin $\mathrm{Kim}^{2,6}$ \\ Mizbebe Obstetrics and Gynecology \\ ${ }^{2}$ Division of Life Science \\ College of Natural Sciences and \\ Institute of Basic Natural Sciences \\ ${ }^{3}$ Department of Pathology, College of Oriental Medicine \\ ${ }^{4}$ Department of Parasitology \\ ${ }^{5}$ Department of Pathology, School of Medicine \\ Wonkwang University, Iksan, Chunbuk 570-749, Korea \\ ${ }^{6}$ Corresponding author: Tel, 82-63-850-6578; \\ Fax, 82-63-857-8837; E-mail, wsnkim@wonkwang.ac.kr
}

Accepted 16 April 2003

Abbreviations: $3 \beta-H S D, 3 \beta$-hydroxysteroid dehydrogenase/ $\Delta^{5}-\Delta^{4}$ isomerase; $\mathrm{DAB}$, diaminobenzidine; DHEA, dehydroepiandrosterone; P450c11, 11ß-hydroxylase; P450c17, 17-hydroxylase; P450c21, 21-hydroxylase; P450scc, P450 side chain cleavage enzyme; RT, reverse transcription

\begin{abstract}
The enzyme complex $3 \beta$-hydroxysteroid dehydro-

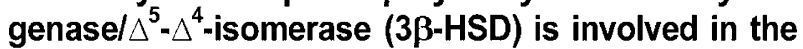
biosynthesis of all classes of active steroids. The expression of $3 \beta-H S D$ in human uterine endometrium during the menstrual cycle and decidua was examined in an effort to understand its role during

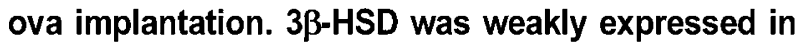
the glandular epithelium of the proliferative phase and moderately expressed in the glandular epithelium of secretory phase of the endometrium. In the decidua of the ectopic pregnancy, $3 \beta-H S D$ was strongly expressed. The human uterine endometrial $3 \beta$-HSD was identified as being the same type

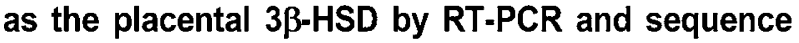

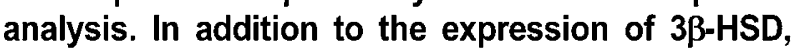
P450scc was expressed in the decidua of the ectopic pregnancy. These results suggest that pregnenolone might be synthesized from cholesterol by P450scc de novo and then, it is converted to progesterone by $3 \beta-H S D$ in the uterine endometrium. The data implies that the endometrial
\end{abstract}

$3 \beta-H S D$ can use not only the out-coming pregnenolone from the adrenal gland but also the selfmade pregnenolone to produce progesterone. The de novo synthesis of progesterone in the endometrium might be a crucial factor for implantation and maintenance of pregnancy.

Keywords: 3B-HSD; decidua; P450scc; progesterone; uterine endometrium

\section{Introduction}

The periodic change of human uterine endometrium during the menstrual cycle depends on steroid hormones produced by the ovary (Tseng et al., 1974; Buirchell and Hahnel, 1975; Pack et al., 1978; Clarke et al., 1982). Since the activity of enzymes involved in steroidogenesis and the periodic change of steroid hormone receptors were identified in human uterine endometrium, the endocrinological role of uterine endometrium has been more complicated (Lessey et al., 1988; Tseng and Zhu, 1997; Matsuzaki et al., 1999).

$3 \beta$-hydroxysteroid dehydrogenase $/ \Delta^{5}-\Delta^{4}$-isomerase (3 3 -HSD, EC 1.1.1.145), which catalyzes the formation of $\Delta^{4}$-3-ketosteroids from $\Delta^{4}$-3-hydroxysteroids, plays an important role in biosynthesis of all classes of hormonal steroids, namely glucocorticoids, mineralocorticoids, progesterone, androgens, and estrogens (Readhead et al., 1983). The enzymatic activity of human $3 \beta-H S D$ is present in not only the classical steroidogenic tissues such as placenta, adrenal glands and gonads (Luu-The et al., 1989; Lorence et al., 1990; Rheaume et al., 1991; Labrie et al., 1992), but also in many peripheral tissues including prostate, breast, skin, liver, lung and heart (Abul- Hajj et al., 1975; Milewich et al., 1977; Lacoste et al., 1990; Dumont et al., 1992; Kayes-Wandover and White, 2000).

Enzymatic activity of $3 \beta-H S D$ in human endometrial tissues was also reported (Seki et al., 1987; Tang et

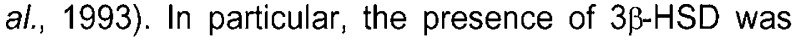
detected by Western blotting as a $42 \mathrm{kDa}$ band in primary endometrium (Tang et al., 1993). In addition to human endometrium, enzymatic activity of $3 \beta-H S D$ was also reported in the myometrium and endometrium of rhesus monkeys (Martel et al., 1994) and in the uteri of rats (Zaho et al., 1991). Therefore, it was assumed that the $3 \beta-\mathrm{HSD}$ of the endometrium involved in the local metabolism of circulating steroids of adrenal origin. However, the expression of P450 
side chain cleavage enzyme (P450scc, EC 1.14.15.6) which catalyzes the first and key regulatory reaction controlling the production of steroid hormones, was identified in the mouse decidua induced by implantation. Thus, it was presumed that, during the early phases of pregnancy, local progesterone synthesis in the maternal deciduas is important for successful implantation and/or maintenance of pregnancy in mice (Ben-Zimra et al., 2002). So far, there has been no report of any evidence of de novo synthesis of progesterone in human uterine endometrium.

Our research was designed to examine the presence of $3 \beta-H S D$ in the endometrium at the level of protein and gene expression by Western blotting analysis, immunohistochemistry and reverse transcription RT-PCR. To determine whether progesterone might be synthesized de novo or not and whether other steroids such as mineralocorticoids and glucocorticoids might also be synthesized in human uterine endometrium, we have also examined the expression of P450scc, 17-hydroxylase (P450c17, EC 1.14.99.9), 21-hydroxylase (P450c21, EC 1.14.99.10) and $11 \beta$ hydroxylase (P450c11, EC 1.14.15.4) by RT-PCR.

\section{Materials and Methods}

\section{Collection of tissues}

The human uterine endometrium were obtained from proliferative phase, secretory phase and ectopic pregnancy. The human placental tissues were also obtained immediately after delivery.

\section{RT-PCR analysis}

Total RNA was prepared by using RNeasy Mini Kit (Qiagen, Chatsworth, CA). Oligonucleotide primers used for RT-PCR (Table 1) were located in two different exons of each gene to avoid amplification of any contaminating genomic DNA. The PCR primer pairs for $3 \beta \mathrm{HSD}-820$ were designed with common sequences to two types of human $3 \beta-H S D$ isoform, and the reverse primer for $3 \beta \mathrm{HSD}-628$ was specific to human placenta type $3 \beta-H S D$. After PCR, the 820 bp product for $3 \beta \mathrm{HSD}-820$ primer was cloned into $\mathrm{pGEM}-\mathrm{T}$ easy vector system (Promega), and sequenced by $A B I$ Prism Big-Dye method (Perkin Elmer) using T7 primer and Sp6 primer.

\section{Western blot analysis}

Anti-3 $\beta$-HSD antibodies were kindly provided by $\mathrm{Dr}$ Luu-The, Laboratory of Molecular Endocrinology, CHUL Research Center, Quebec, Canada. Placental and endometrial tissue samples were homogenized in lysing solution ( $1 \%$ sodium deoxycholate, $0.1 \%$ sodium do- decyl sulfate, and $0.8 \mathrm{mM}$ phenylmethylsulfonyl fluoride in PBS). Homogenates were centrifuged at 1,500 $g$ for $15 \mathrm{~min}$. Protein concentrations were determined using the Bio-Rad Protein Assay reagent with bovine serum albumin as a standard. Protein extracts $(6 \mu \mathrm{g}$ for placenta and $25 \mu \mathrm{g}$ for endometrium) were electrophoresed in an 12\% SDS-polyacrylamide gel under reducing conditions, electroblotted onto an Immobilon$P$ membrane (Millipore), and detected with the anti$3 \beta-H S D$ antibodies in the previously described manner (Lim et al., 2002).

\section{Histologic and immunohistochemical stain}

The specimens from patients were fixed in $10 \%$ buffered formalin and embedded in the paraffin. Four micrometer sections were cut and hematoxylin eosin stain was performed. For immunostaining, four micrometer sections were cut on the Probe-on plus slide (Research genetics, $A L$ ), heated at $60^{\circ} \mathrm{C}$ for $30 \mathrm{~min}$, and deparaffinized by xylene. Next, tissue sections were rehydrated in phosphate-buffered saline (PBS) solution, and then the slides were blocked in $3 \%$ hydrogen peroxide for $10 \mathrm{~s}$. The slides were washed twice in Immuno/DNA buffer solution (Research genetics, $A L)$ and then incubated in protein blocker solution (Research genetics, $A L$ ) for $3 \mathrm{~min}$. The sections were incubated overnight at $4^{\circ} \mathrm{C}$ with the $3 \beta-H S D$ antibodies which was diluted to $1: 200$ by antibody diluent (Research genetics, $A L$ ) and incubated with the universal secondary antibody (Research genetics, $\mathrm{AL}$ ) for $8 \mathrm{~min}$. The sections were labeled with peroxidase-conjugated streptoavidin (Research genetics, $\mathrm{AL}$ ) for $10 \mathrm{~min}$, and incubated in diaminobenzidine (DAB) for $10 \mathrm{~min}$ and washed in Immuno/DNA (Research genetics, $A L)$. Finally, the slides were counterstained with Mayer's hematoxylin, washed in distilled water, and mounted by universal mount (Research genetics, $A L)$.

\section{Results}

\section{Western blot analysis for 3 $\beta$-HSD}

Human placental $3 \beta-H S D$ (type I) which was expressed strongly in human placenta was already identified by molecular cloning and Western blot analysis (LuuThe et al., 1989; Lachance et al., 1990; Lorence et al., 1990). The protein of $3 \beta-H S D$ was detected by Western blotting as a $42 \mathrm{kDa}$ band in a human endometrial tissue (Tang et al., 1993). We examined whether the endometrial $3 \beta-\mathrm{HSD}$ could cross-react with anti-placental $3 \beta-H S D$ antibody which was provided by Dr Luu-The. The antibody detected the endometrial $3 \beta-\mathrm{HSD}$ as a $42 \mathrm{kDa}$ band which was the 

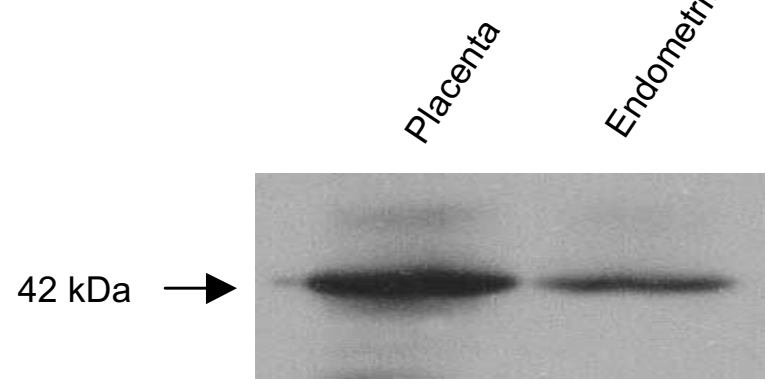

Figure 1. Western blot analysis. The samples (containing $6 \mu \mathrm{g}$ or 25 $\mu \mathrm{g}$ protein) extracted from the human placenta and uterine endometrium were electrophoresed in an SDS-polyacrylamide gel under reducing conditions, and detected with the anti-3ß-HSD antibody as described under Materials and Methods. same band as the placental $3 \beta-H S D$ (Figure 1).

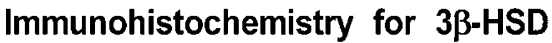

We examined the change of $3 \beta-H S D$ expression according to the morphological change of uterine endometrium using immunohistochemistry. When the choronic villi which express type I 33-HSD (Mason et al., 1997), was applied as a control, the cytotrophoblasts and syncithiotrophoblasts were stained strongly with anti-3B-HSD antibody (Figure 2A). We prepared the endometrial tissues of the proliferative and secretory phase from the normal woman and decidua from the woman with ectopic pregnancy to prevent contamination of any chorionic villi, and then the samples

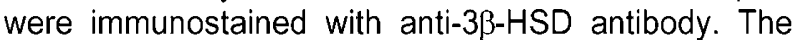
glandular epithelium of the proliferative phase was very weakly, the glandular epithelium of the secretory phase was moderately, and the decidua was strongly

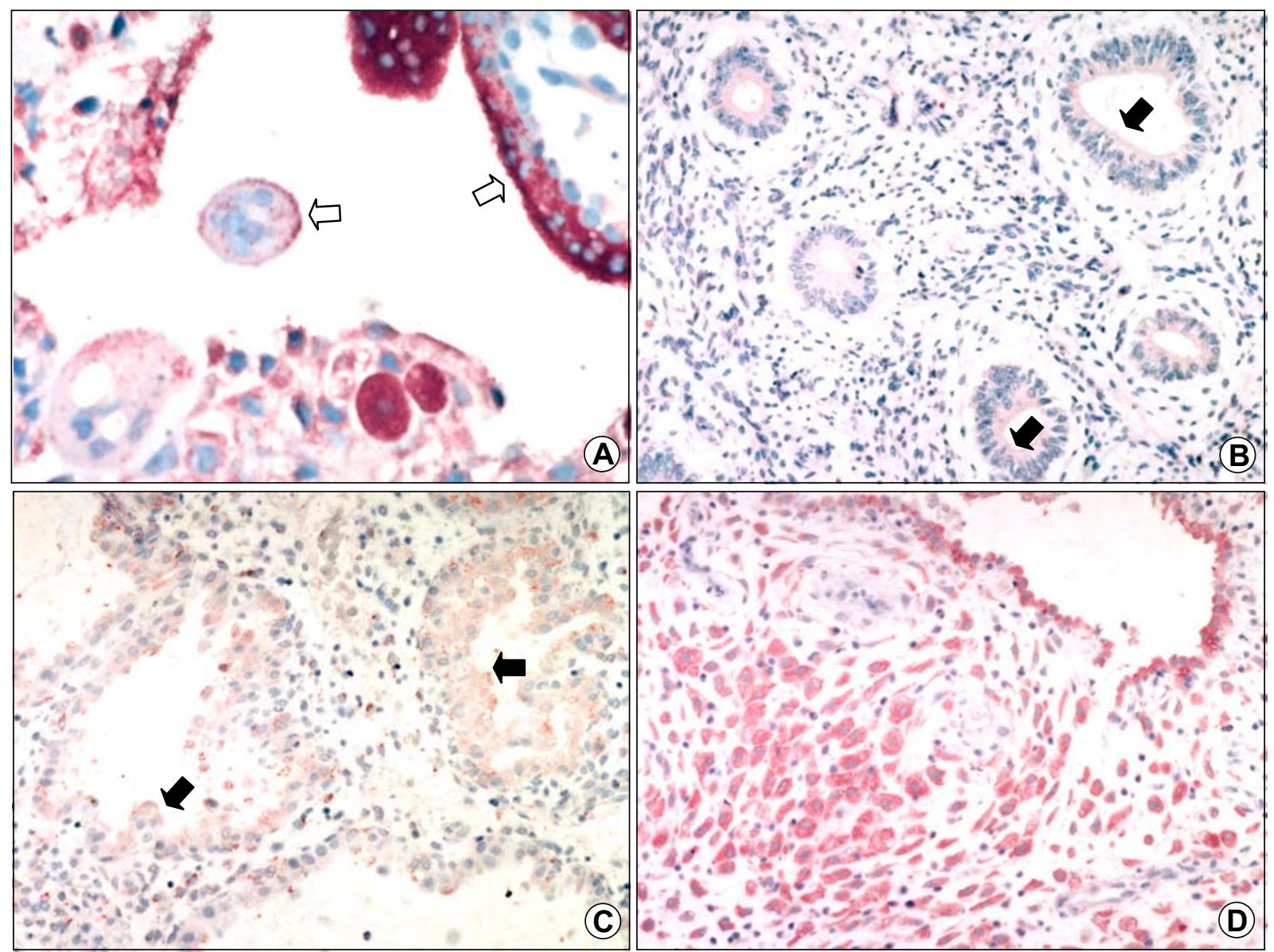

Figure 2. Immunohistochemistry of 3B-HSD. The cytotrophoblasts and syncithiotrophoblasts of the chorionic villi (A) and the decidua (D) were strongly stained, the glandular epithelium of the secretory phase of the endometrium (C) was moderately stained, and the glandular epithelium

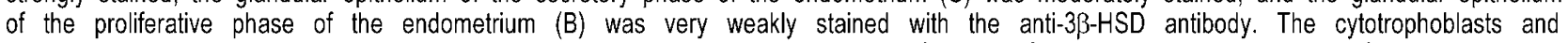
syncithiotrophoblasts were indicated by open arrows and the glandular epithelium of the proliferative and secretory phase of the endometrium were indicated by closed arrows. 


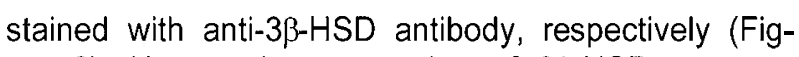
ure 2). Hence, the expression of $3 \beta-H S D$ was enhanced with increase of progesterone concentration in uterine endometrium.

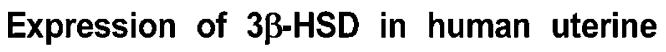 endometrium}

We next confirmed the expression of $3 \beta-H S D$ on mRNA level and determined which type of $3 \beta-H S D$ is expressed in uterine endometrium. We designed two primer sets for RT-PCR; one was the common to type I and II 33-HSD, namely $3-\beta H S D-820$, and the

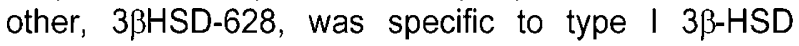
(Table 1). Using the 3BHSD-820 primer set, the 820 bp band was obtained in the endometrial sample. The

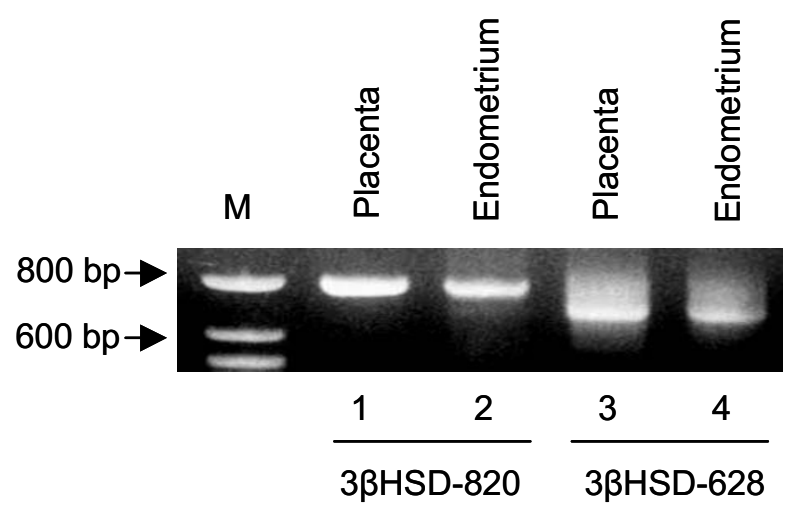

Figure 3. RT-PCR analysis of $3 \beta-H S D$. The same band in the endometrial sample as that of placenta sample was obtained with $3 \beta$ -

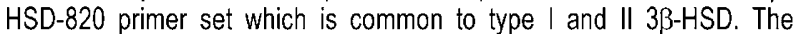
$628 \mathrm{bp}$ band was also detected in the placenta and the endometrial sample by the type I specific 3ß-HSD-628 primer set. band is the same as the $820 \mathrm{bp}$ band obtained in placenta sample which is expressed type I 3B-HSD. In the case of $3 \beta \mathrm{HSD}-628$ primer set, the same 628 $\mathrm{bp}$ band as those of placenta sample was also detected in the endometrial sample (Figure 3). The $820 \mathrm{bp}$ band was subcloned into the pGEM-T easy vector system and sequenced. The nucleotide sequences of the $820 \mathrm{bp}$ were completely identical to those

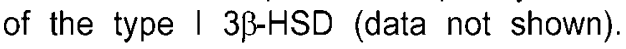

\section{Expression of P450scc in Human Uterine endometrium}

Next, to see whether progesterone might be synth-

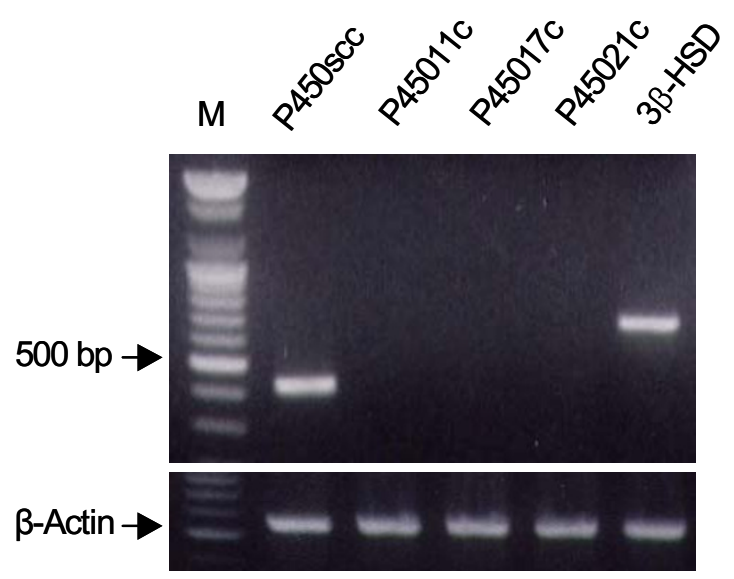

Figure 4. RT-PCR analysis of steroidogenic enzymes. I $\mu \mathrm{g}$ of total RNA was used for first strand CDNA synthesis. PCR amplification was performed with the specific primer set for P450scc, P45011c, P45017c, P45021c and 3B-HSD (Table 1). The PCR products of P450scc and $3 \beta-H S D$ primer set were detectable in the uterine endometrium of ectopic pregnancy.

Table 1. Sequences of oligonucleotides.

\begin{tabular}{|c|c|c|c|c|}
\hline Gene & $5 \rightarrow 3$ Oligonucleotide sequence & Strand & Exon & Product size (bp) \\
\hline \multirow[t]{2}{*}{ P450scc } & CAG TGG CAC TTG TAT GAG ATG & + & 6 & 420 \\
\hline & TTG GTC ATC TCT AGC TCA GCG & - & 8 & \\
\hline \multirow[t]{2}{*}{$3 \beta H S D-820$} & AGT GAT TCC TGC TAC TTT GG & + & 1 & 820 \\
\hline & TAG CTT TGG TGA GGC GTG TC & - & 3 & \\
\hline \multirow[t]{2}{*}{$3 \beta H S D-628$} & AGT GAT TCC TGC TAC TTT GG & + & 1 & 628 \\
\hline & CTA GCA GAA AGG AAT CGG CT & - & 3 & \\
\hline \multirow[t]{2}{*}{ P450c17 } & GTA TCG CCT TCG CTG ACT CTG & + & 2 & 632 \\
\hline & ATT GTG CAG CAG GAA GGC CAG & - & 5 & \\
\hline \multirow[t]{2}{*}{ P450c21 } & TGA GAT TCA GCA GCG ACT GC & + & 6,7 & 417 \\
\hline & GTG AAG GCC TGC AGC AGT CG & - & 8 & \\
\hline \multirow[t]{2}{*}{ P450c11 } & TTC CAG TAC GGC GAC AAC TG & + & 4,5 & 565 \\
\hline & CCA AGG CAC TGG CGC ATG CC & - & 8 & \\
\hline
\end{tabular}


esized de novo in the uterine endometrium, we examined the expression of genes for steroidogenic enzymes, P450 scc, P450c17, P450c21 and P450c11, as well as $3 \beta-H S D$ using RT-PCR. The specific primers used for RT-PCR (Table 1) were located in two different exons of each gene to avoid amplification of any contaminating genomic DNA. In addition to $3 \beta$ HSD, only P450scc mRNA was detectable in the uterine endometrium sample after 30 PCR cycles (Figure 4). This result suggests that pregnenolone might be synthesized from cholesterol de novo by P450scc and the pregnenolone could be converted to progesterone by $3 \beta-H S D$ in the uterine endometrium.

\section{Discussion}

As a result of endocrine stimulation, regular morphologic changes occur in human uterine endometrium. The concentration of progesterone in the secretory phase is higher than that in the proliferative phase of menstrual cycles, while vice versa for the concentration of estradiol. During the secretory phase of menstrual cycles, endometrial stromal cells differentiate into decidual cells which play a crucial role in implantation and maintenance of pregnancy. Decidualization is thus a progesterone-induced differentiation of the estrogen-primed endometrial stromal cells, and a key factor in regulating decidualization of endometrial stromal cells might be progesterone originated from ovarian sources (Irwin et al., 1989; Fujimoto et al., 1996; Brar et al., 1997).

Enzymatic activity of $3 \beta-H S D$ was detected in human uterine endometrial tissues. In addition to the enzymatic activity of $3 \beta-H S D$ in human endometrium, the presence of $17 \beta-H S D$, which controls the last step in the formation of all androgens and all estrogens in gonadal as well as extra-gonadal tissues, was also reported in the human endometrium (Pollow et al., 1975; Seki et al., 1987; Maentausta et al., 1991; Mustonen et al., 1998). Moreover, aromatase activity in the endometrium was also reported (Yamamoto et al., 1993). Therefore, those results suggested that human endometrium could produce biologically active steroids from circulating precursors of adrenal origin. Because progesterone plays an important role in implantation and maintenance of pregnancy, the concentration of progesterone in the secretory phase is significantly higher than in the proliferative phase. Hence, the expression of endometrial $3 \beta-H S D$ might be enhanced with the increase of circulating concentration of gonadotrophic hormones. However, some reports showed the different results about the enzymatic activity of $3 \beta-H S D$ during the menstrual cycle (Seki et al., 1987; Tang et al., 1993).

If the endometrium acts actively as a paracrine or autocrine tissue, it was assumed that the level of $3 \beta-H S D$ concentration in endometrium should be changed during the menstrual cycle and maintained highly during gestation. In this study, we have examined the expression of $3 \beta-H S D$ in human uterine endometrium during the menstrual cycle and in decidua by immunohistochemistry. We estimated the expression level of $3 \beta-H S D$ depending on the staining level. The expression of $3 \beta-H S D$ in the proliferative phase was very low, whereas the expression in the secretory phase was increased (Figure 2). 3 $3-\mathrm{HSD}$ was expressed more strongly in the decidua of ectopic pregnancy. This result is in accordance with the increase of progesterone concentration in the secretory phase of menstrual cycles. The $3 \beta-H S D$ expressed in the uterine endometrium was identified as being the same type as the placental $3 \beta-H S D$ (type I) by RT-PCR and sequencing analysis (Figure 3 ).

Next, to see whether progesterone might be synthesized de novo and whether other sterioids such as aldosterone and cortisol might be synthesized in uterine endometrium, we examined the expression of genes which encoded steroidogenic enzymes as well as $3 \beta-H S D$. The first and rate-limiting step in the biosynthesis of all steroid hormones is the conversion of cholesterol to pregnenolone by the mitochondrial cytochrome P450scc. If P450scc may be expressed in uterine endometrium, pregnenolone might be synthesized from cholesterol de novo. Once pregnenolone is produced from cholesterol, it may undergo $17 \beta-H S D$ hydroxylation to 17-hydroxypregnenolone, or it may be converted to progesterone by $3 \beta-H S D$. Both pregnenolone and progesterone may be $17 \beta$-hydroxylated to 17-hydroxypregnenolone and hydroxyprogesterone, respectively, and these steroids may then undergo the scission of $\mathrm{C} 17,20$ carbon bonds to yield dehydroepiandrosterone (DHEA) and androstenedione by a single enzyme, $\mathrm{P} 450 \mathrm{c} 17$, respectively (Nakajin et al., 1981). If the expression of $\mathrm{P} 450 \mathrm{c} 17$ gene is not detectable, pregnenolone is converted to mineralocorticoids; if $\mathrm{P} 450 \mathrm{c} 17$ gene is expressed and $P 450 \mathrm{C} 21$ and $\mathrm{P} 450 \mathrm{c} 11$ gene is expressed, pregnenolone is converted to the glucocorticoid, cortisol. We have examined the expression of these steroidogenic enzymes: P450scc, 3 $\beta$-HSD, P450c17, P450c21 and P450c11, using RT-PCR in uterine endometrium of the ectopic pregnancy. The specific primers used for RT-PCR (Table 1) were located in two different exons of each gene to avoid amplification of any contaminating genomic DNA. In addition to $3 \beta-\mathrm{HSD}$, only P450scc mRNA was detectable in uterine endometrium sample after 30 PCR cycles (Figure 4). Up to date, because the enzyme activity of $3 \beta-H S D, 17 \beta-$ HSD and P450aro was detected in the uterine endometrium where there were believed to use merely the circulating steroids of adrenal origin for synthe- 
sizing progesterone and estrogen. However, this result suggests that during the early phase of pregnancy, the endometrial $3 \beta-H S D$ can use not only the out-coming pregnenolone from the adrenal gland but also the self-made pregnenolone to produce progesterone. Ben-Zimra et al. suggested that the expression of P450scc and 3 $\beta-H S D$ type VI gene in mouse deciua is important for successful implantation and/or maintenance of pregnancy. They also proposed that the local production of progesterone acts as an immunosuppressant at the maternofetal interface preventing the rejection of the fetal allograft (Ben-Zimra et al., 2002). In this context, the expression of p450scc and $3 \beta-H S D$ gene in human uterine endometrium has a significant meaning for implantation and maintenance of pregnancy. Although we couldn't confirm the expression of P450scc in the endometrium during the menstrual cycle, the de novo synthesis of progesterone might be especially important for regulating the decidualization of endometrial stromal cells. To address this question experiments are underway in our laboratory.

\section{Acknowledgement}

We would like to thank Dr. Luu-The, Laboratory of Molecular Endocrinology, CHUL Research Center,

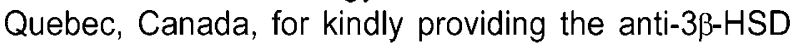
antibody. This study was supported by Korea Science and Engineering Foundation (KOSEF) and Chonbuk Provicial Government through the Medical Resources Center at Wonkwang University and partially by the Wonkwang University in 2002.

\section{References}

Abul-Hajj TJ. Metabolism of dehydroepiandrosterone by hormone dependent and hormone independent human breast carcinoma. Steroids 1975;26:488-500

Ben-Zimra M, Koler M, Melamed-Book N, Arensburg J, Payane $A H$, Orly J. Uterine and Placental expression of steroidogenic genes during rodent pregnancy. Mol Cell Endocrinol 2002;187:223-31

Brar AK, Frank GR, Kessler CA, Cedars MI, Handwerger S. Progesterone-dependent decidualization of the human endometrium is mediated by cAMP. Endocrine 1997;6:301-7

Buirchell BJ, Hahnel R. Metabolism of estradiol-17 $\beta$ in human endometrium during the menstrual cycle. J Steroid Biochem 1975;6:1489-94

Clarke CL, Adams JB, Waren BG. Induction of estrogen sulfotransferase in the human endometrium by progesterone in organ culture. J Clin Endocrinol Metab 1982;55:70-5

Dumont M, Luu-The Van, Dupont E, Pelletier G, Labrie F. Characterization, expression and immunohistochemical localization of $3 \beta$-hydroxysteroid dehydrogenase $/ \Delta^{5}-\Delta^{4}$ isomerase in human skin. J Invest Dermatol 1992;99:415-21

Fujimoto $M$, Kanzaki $H$, Nakayama $H$, Higuchi $T$, Hatayama $\mathrm{H}$, Iwai M, Kaneko $\mathrm{Y}$, Mori T, Fujita J. Requirement for transglutaminase in progesterone-induced decidualization of human endometrial stromal cells. Endocrinology 1996;137: 1096-101

Irwin JC, Kirk D, King RJ, Quigley MM, Gwatkin RB. Hormonal regulation of human endometrial stromal cells in culture: an in vitro model for decidualization. Fertil Steril 1989; 52:761-68

Kayes-Wandover KM, White PC. Steroidogenic enzyme gene expression on the human heart. J Clin Edocrinol Mtab 2000; 85:2519-25

Labrie F, Simard J, Luu-The V, Pelletier G, Belanger A, Lachance $Y$, Zhao HF, Labrie $C$, Breton $N$, de Launoit $Y$, Dumont M, Dupont E, Rheaume E, Martel C, Couet J, trudel C. Structure and tissue-specific expression of 3beta- hydroxysteroid dehydrogenase/5-ene-4-ene isomerase genes in human and rat classical and peripheral steroidogenic tissues. J Steroid Biochem Mol Biol 1992;41:421-35

Lachance $Y$, Luu-The V, Labrie C, Simard J, Dumont M, de Launoit Y, Guerin S, Leblanc G, Labrie F. Characterization of human 3 beta-hydroxysteroid dehydrogenase/delta 5-delta 4-isomerase gene and its expression in mammalian cells. J Biol Chem 1990;265:20469-75

Lacoste D, Belanger A, Labrie F. Biosynthesis and degradation of androgens in human prostatic cancer cell lines. In: Bradlow H, Castagnetta L, d'Aquino S, Labrie F (eds) Steroid formation, Degradation and Action in Peripheral, Normal and Neoplastic Tissues. New York Acad Sci 1990; 595:389-91

Lessey BA, Killam AP, Metzger DA, Haney AF, Greene GL, and McCarty KS Jr. Immunohistochemical analysis of human uterine oestrogen and progesterone receptors throughout the menstrual cycle. J Clin Endocrinol Metab 1988;67:334-40

Lim SY, Lee SC, Shin I, Han JS. Differential effects of Fas cross-linking on phospholipase $D$ activation and related lipid metabolism in Fas-resistant A20 cells. Exp Mol Med 2002; 34:201-10

Luu-The V, Lachance Y, Labrie C, Leblanc G, Thomas JL, Strickler RC, Labrie F. Full length cDNA structure and deduced amino acid sequence of human 3 3 -hydroxy-5-ene steroid dehydrogenase. Mol Endocrinol 1989;3:1310-2

Maentausta O, Sormunen R, Isomaa V, Lehto VP, Jouppila P, Vihko R. Immunohistochemical localization of 17 betahydroxysteroid dehydrogenase in the human endometrium during the menstrual cycle. Lab Invest 1991;65:582-7

Martel C, Melner MH, Gagne D, Simard J, Labrie F. Widespread tissue distribution of steroid sulfatase, 3beta- hydroxysteroid dehydrogenase/delta5-delta4 isomerase (3betaHSD), 17beta-HSD 5 alpha-reductase and aromatase activities in the rhesus monkey. Mol Cell Endocrinol 1994;104: 103-11

Mason JI, Keeney DS, Bird IM, Rainey WE, Morohashi K, Leers-Sucheta $\mathrm{S}$, Melner MH. The regulation of $3 \beta$ - hydroxysteroid dehydrogenase expression. Steroids 1997;62:164- 
Matsuzaki S, Fukaya T, Suzuki T, Murakami T, Sasano $\mathrm{H}$, and Yajima A. Oestrogen receptor alpha and beta mRNA expression in human endometrium throughout the menstrual cycle. Mol Hum Reprod 1999;5:55964.

Milewich L, Winters AJ, Stephens P, MacDonald PC. Metabolism of dehydroisoandrosterone and androstenedion by the human lung in vitro. J Steroid Biochem 1977;8:277-84

Mustonen MV, Isomaa VV, Vaskivuo T, Tapanainen J, Poutanen $\mathrm{MH}$, Stenback F, Vihko RK. Human 17beta-hydroxysteroid dehydrogenase type 2 messenger ribonucleic acid expression and localization in term placenta and in endometrium during the menstrual cycle. J Clin Endocrinol Metab 1998;83:1319-24

Nakajin S, Shively JE, Yuan P, Hall PF. Microsomal cytochrome $P 450$ from neonatal pig testis: two enzymatic activities (17 $\alpha$-hydroxylase and C17,20-lyase) associated with one protein. Biochemistry 1981;20:4037-42

Pack BA, Tovar R, Booth E, Brooks SC. The cyclic relationship of estrogen sulfurlation to the nuclear receptor level in human endometrial curettings. J Clin Endocrinol Metab 1979:48:420-4

Readhead C, Lobo RA, Kletzky OA. The activity of 3 betahydroxysteroid dehydrogenase and delta 4-5 isomerase in human follicular tissue. Am J Obstet Gynecol 1983;145: 491-5

Rheaume E, Lachance $\mathrm{Y}$, Zhao HF, Breton N, de Launoit Y, Trudel C, Luu-The V, Simard J, Labrie F. Structure and expression of a new cDNA encoding the almost exclusive
$3 \beta$-hydroxysteroid dehydrogenase $/ \triangle^{5}-\triangle^{4}$ isomerase in human adrenals and gonads. Mol Endocrinol 1991;5:1147-57

Seki M, Hara Y, Sekiya M, Itagaki T, Hirato K, Yanaihara T, Nakayama T. Changes in steroid enzyme activity in the human endometrium during the menstrual cycle. Nippon Sanka Fujinka Gakkai Zasshi 1987;39:1571-8

Tang B, Markiewicz L, Kloosterboer HJ, Gurpide E. Human endometrial 3 beta-hydroxysteroid dehydrogenase/isomerase can locally reduce intrinsic estrogenic/progestagenic activity ratios of a steroidal drug (Org OD14). J Steroid Biochem Mol Biol 1993:45:345-51

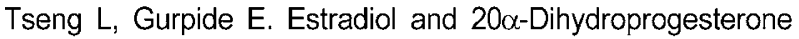
dehydrogenase activities in the human endometrium during the menstrual cycle. Endocrinol 1974;94(2):419-23

Tseng $\mathrm{L}$, and $\mathrm{Zhu} \mathrm{HH}$. Regulation of progesterone receptor messenger ribonucleic acid by progestin in human endometrial stromal cells. Biol Reprod 1997;57:1360-6

Yamamoto T, Kitawaki J, Urabe M, Honjo H, Tamura T, Noguchi T, Okada H, Sasaki H, Tada A, Terashima $Y$. Estrogen productivity of endometrium and endometrial cancer tissue; influence of aromatase on proliferation of endometrial cancer cells. J Steroid Biochem Mol Biol 1993;44:463-8

Zaho HF, Labrie C, Simard J, DE Launoit Y, Trudel C, Martel C, Rheaume E, Dupont E, Luu-The V, Pelletier G, Labrie $F$. Caracterization of $3 \beta$-hydroxysteroid dehydrogenase $/ \Delta^{5}$ $\triangle^{4}$ isomerase cDNAs and differentiation tissue-specific expression of the corresponding mRNAs in steroidogenic and peripheral tissues. J Biol Chem 1991;266:583-93 